\title{
SEREA
}

Dynamic Determination of the

Compressibility of Metals

\section{List of Author:}

Roy W. Goranson, Demison Bancroft, Blendin L. Burton, Theodore Blechar, Edwin E. Houston, Blisabeth F. Gittings, Stanley A. Landeon

\section{Acknowledgements}

Gordon Waters, S. W. Bale, Earl Faudreo, George Cody

$\boldsymbol{\gamma}$

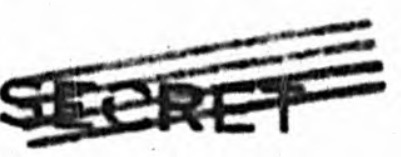




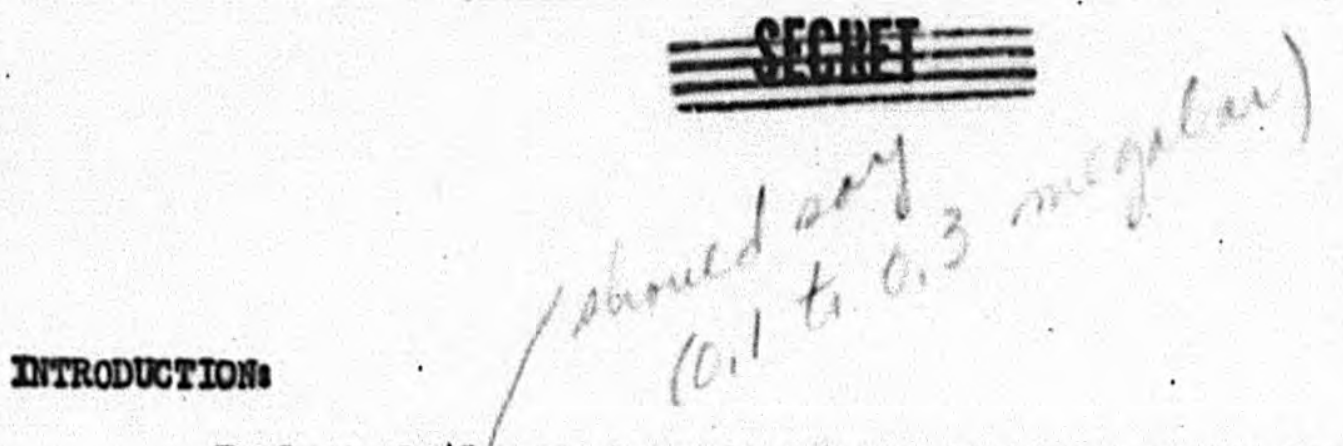

Berly in 19/45/experimental work vas initiated at the Los Alarnos Scientific Laboratory for the study of physical proporties of naterials in the prescure range frow 0.1 to 1 megabar $\left(10^{22}\right.$ dynes $\left./ \mathrm{cm}^{2}\right)$. One-tenth of a megabar had been obtained staticaliy at the Ceophyalcal Laboratory of the Carnegle Inst1tution, but doterainations of the equation of state at this pressuro becone Inpractical partly because of the elaborate and cumbersome apparatus required and partiy because static meacuronents are subject to uncertaintles resulting from oreep d1stortions. An alternative technique, and one partioularly suited to the data here desired, is to make the meecuraments dymalcally, thorety elininating the need for elaborato high pressuro equipnent with 1ts inherent oreep unoficainties. It 18, of course, well known that extreme, though tonporary, pressures can be devaloped by high explosives. With sultably designed apparatus, detonation of a high explosive may be made to produce in the material being investigated a plano shook wave approximately flat topped in the sense that the prossure in the compressed material is virtually independent of position. The conditions for the existence and stabllity of such shook waves are discussed in a varloty of text books.

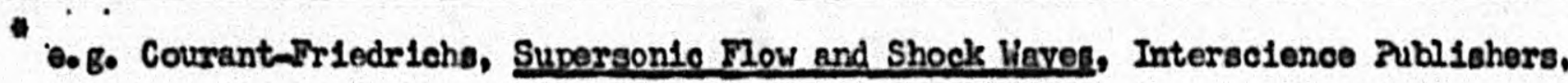
1948 , p. 121 et seg.

The theory of propagation of such waves 1mplios that elmultaneous detorrinations of the propagation velocity of the wave and of the mass relocity of the conpressed material can be used to infer the equation of state. In addition it is possibie under certain conditions to deternine shock pressures by meens of plezoelectric erystals though this last technique has proved rather diffioult to exploit.

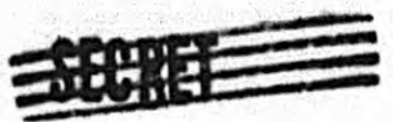




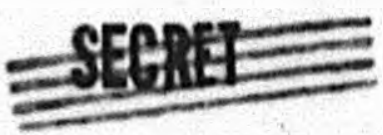

$-2-$

Table I. Definitions of symbols and 1 sst of units to be used in computat10n.

Symbol

p

$\checkmark$

$p$

P。

$\eta-1=\mu$
Definition

Pressure

Speciflc volume

Density at pressure $p$

Instial density

Compression $-1=\left(p-p_{0}\right) / p_{0}$
Ondts

Negabar $=10^{12}$ dynes $/ \mathrm{c}^{2}$

$\mathrm{con}^{3} / \mathrm{O}$

$\mathrm{cm} / \mathrm{cm}^{3}$

n

Compression is alternotudydefined as $\left(\nabla_{0}-\nabla\right) / \nabla_{0}=(\eta-2) / \eta$, where $\nabla_{0}$ is the norral spectelo volume.

- Specific Internal enere

I Aboolute temperature

- Specific ontropg

C Specific heat at oonstant

volue $=\left(\frac{\partial \theta}{\partial g}\right) \nabla$

D Shook wave veloolty

u Particlo or mass veloelty

- Excess of free aurface

velocity over mass velocity

Velocity of sound $=\left(\frac{\partial p}{\delta p}\right)_{s}^{1 / 2}$

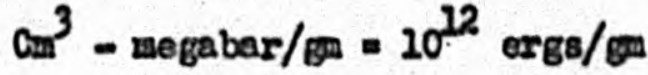

Electron Volt $=\mathrm{Kr}=21,605^{\circ} \mathrm{C}$

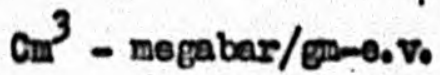

$\mathrm{Cm} /$ milcrosiecond $=\mathrm{Cm} / 10^{-6}$ sec.

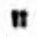

$\mathbf{n}$

it 


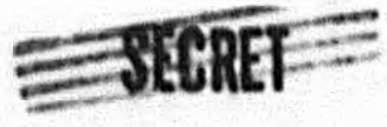

THEOTS

Detonation of $\mathrm{hlgh}$ explosive in oontact with a metall10 specimen produces pressures in the metal under what are urvally tormed "Rankine-llugoniot Shock" conditions. Such conditions will be denoted by appending tho subseript D to the aymbols appearing in Table I. The mochanions considerations of conservation of mass and conservation of monentum respectivoly load to tho equat1onss

$$
\begin{aligned}
& \eta-1=\mu-w /(D-u) \\
& P_{D}=P_{0} D u
\end{aligned}
$$

The pressures and compressions appearing in Tables II and III were computed by means of Eqs. (1) and (2). For mans purposes, for exomple in comparing our data with other data, it is necessary to know the relationshlp between pressure and compression either at constant entropy or at constant tenperature. Such conditions will be speolfled by the subseripto. and I respectively. In order to compute the alfference between $P_{D}$ and $P_{B}$ or $P_{T}$ for some specifiod conpression $\eta_{\text {, one }}$ requires an additional shook condition besed on thermodynamic conservation of onerger

$$
\Delta D_{D}=1 / 2 B_{D}\left(\nabla_{0}-\nabla\right)
$$

where ${ }_{\mathrm{D}}$ represents the internal energy change required to reach the shock preosure $P_{D}$ at the finel specifle volume $\nabla$. The energy change required to reach this same final volue 1sentropically may bo found by integration:

$$
\Delta e_{s}=\int_{v}^{v_{0}} p d v
$$

The enerey excese under conditions produced by the shocik is thermal enores. Th1s enerey differencemay be expressed in terme of thermodyamic data by the equatione

$$
\Delta e_{2}-\Delta e_{s}=\int_{p_{0}}^{p_{0}} C_{v}\left(\frac{\partial T}{\delta p}\right)_{v} d p
$$




\section{SECREF}

$-4-$

Equations (3), (4) and (5) when cotbined result in an equation from which the difference $P_{D}-P_{0}$ may be found. Estimates of the Integrand In $E_{q}$. (5) aro avallable, and for our imediate purposes, approprlate moan values can be seleoted with ouffiolent acouracy. In this case an explicit solution for $\left(p_{\mathrm{D}}-p_{\mathrm{B}}\right)$ may be obtained in the oimple forme

$$
p_{s}-p_{s}=\frac{\frac{1}{2} b_{s}\left(v_{0}-v\right)-\int_{v}^{v_{v}} p d v}{C_{v}\left(\frac{\partial T}{\partial p}\right)_{v}-\frac{1}{2}\left(v_{0}-v\right)} .
$$

In order to solve Eq. (6) a prolininary ostinate 18 mado for $p_{8}$ as a function of $v$ at constant entropy, in which case the numorator of Eg. (6) nay easily be ovaluated. The apec1flod correction may then be applied to tho obeerved shock pressure $\mathrm{p}_{\mathrm{p}}$ and a second approxisation made for the 1sentrople pressurevolume relation. Further approximations can readily bo mado if necessary.

The Infitial free ourface velocity of the target plates with which wo have experimented is approximately twloo the mass velocity. More prodsely, however, the oxcess $\sigma$ of free surface velocity over mass velocity is given by the Riemann velooity

$$
\sigma=\int_{\rho_{0}}^{\rho} c d(\ln \rho)
$$

an expression which may be derived on the assumption that the material compressed by the shock expands isentropioally when traversed by a wave of rarefaction. The diffloulty Involved in ovaluating $\sigma$ steme from the fact that the entropy of the oxpanding material, though constant, is different rrom the original entropg, and accordingly to deternine the 1sentropic equation of state the experimental data require correction. Before considaring the corrections nocessary it is convenlent to tranaform Eq. (7) to tho form

$$
\sigma=\int_{0}^{A}\left(\frac{\partial v}{\partial p}\right)_{s}^{\frac{1}{2}} d p
$$

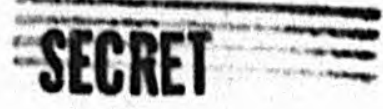




\section{SEGREF}

Eveluation of $\sigma$ as specifled in Bq. (8) may bo facillitated by the following artifico. Firat eliminato the shook veloosty D botween Iqs. (1) and (2) obtaining an expression for the mass veloolty $u$ in the form

$$
u=\int_{0}^{p_{0}}\left(\frac{v_{0}-v}{p_{0}}\right)^{\frac{1}{2}} d p
$$

the integrand of which is constant once a particular volume $\nabla$ corresponding to the extresse pressure has beon chosen. Comblining Fq. (8) and (9) there results

$$
\frac{\sigma-u}{u}=\frac{1}{p_{D}} \int_{v}^{v_{0}}\left(1-\sqrt{\left(\frac{\partial v}{\partial p}\right)_{s} \frac{p_{D}}{v-v_{0}}}\right)\left(\frac{\partial p}{\partial v}\right)_{s} d v
$$

Where $\nabla_{1}$ is the final specific volume after the 1sentrople expansion. Equation (10) clearly Implies that for sufficiently woak shook the free surface volocity approaches twice the mass veloolty. Furtherwore approximate values of the Integrand of Eq. (10) auffice to provido on eatimate of the difference botween $u$ and $\sigma$.

In order to determine $\left(\frac{\partial \phi}{\partial V}\right)_{s}$ at the entropy of the shocked material, one may compute the entropy change $\Delta s$ due to the shock, then estimate from avallahle thermodynamic enta the magnitude of $\frac{\partial^{2} p}{\partial s} \partial v$, and thus obtain a corrected value of the desired derivative in the form

$$
\left(\frac{\partial b}{\partial v}\right)_{s}=\left(\frac{\partial p}{\partial v}\right)_{s o}+\frac{\partial^{2} p}{\partial s^{2} \partial v} \Delta s
$$

4 formula for $\frac{\partial^{2} k}{\partial s \partial v}$ in terms of roadily available themodynamic data is

$$
\frac{\partial^{2} p}{\partial s \partial v}=-\frac{T}{C_{v}^{2}}\left(\frac{\partial p}{\partial T}\right)_{v}^{2}+\frac{T}{C_{v}} \frac{\partial^{2} p}{\partial T_{v}}+\frac{T^{2}}{C_{v}^{3}}\left(\frac{\partial p}{\partial T}\right)_{v}^{2}\left(\frac{\partial C_{v}}{\partial T}\right)_{v}-\frac{2 T^{2}}{C_{v}^{2}}\left(\frac{\partial b}{\partial T}\right)_{v}\left(\frac{\partial^{2} p}{\partial T^{2}}\right)_{v}
$$

In which the firgt term on the right is the most important.

The entropy excess $\Delta a$ of the shocked material nay be computed by Integrating with respect to tenperature at the final known volume of the compressed matorial. 


\section{JECPII}

$-6-$

The first stop in this process is to deteraine the 1sentropic tenperature $\mathrm{I}_{\mathrm{g}}$ at the conpressed volume $v$ from the forrula

$$
\ln \frac{T_{s}}{T_{0}}=\int_{v}^{v_{0}} \frac{1}{c_{v}}\left(\frac{\partial p}{\partial T}\right)_{v} d v
$$

Next one determines the shock temperature $I_{D}$ at this sane volume by wens of the rolation

$$
T_{2}-T_{s}=\frac{\Delta e_{2}-\Delta e_{s}}{C_{v}}
$$

The mumerator of Eq. (14) may be evaluated by neans of Eq. (3) and (4), which with the holp of $\mathrm{Eq} .(6)$ may be put in the form

$$
\Delta e_{D}-\Delta e_{s}=\frac{\frac{1}{2} p_{s}\left(v_{0}-v\right)-\int_{v}^{v_{0}} p d v}{1-\frac{v_{0}-v}{2 c_{v}}\left(\frac{\partial p}{\partial \tau}\right)_{v}}
$$

Once $I_{D}$ and $T_{\theta}$ are known, it is very sinple to compute $\Delta$, for

$$
\Delta s=C_{v} \ln \frac{T_{0}}{T_{5}}
$$

It should porhaps be noted that Egs. (14) and (16) are both basod on processes occurring at constant volume, in which of course no mechanical vork is perforned by the system. On the other hand, the Integrals in Egs. (23) and (15) are to bo ovelusted at constant ontropp.

It will be alear that all the corrections to be made depend on Information about the tomperature and volume dependence of the varlous thermodynanic variables. Fortunately $c_{v}$ and $\left(\frac{\partial p}{\partial T}\right)_{v}$ do not vary much under the conditsons covered by the obeervations. The calculations for duralunin have inoluded an estimate of this varlation though it has been found that the final rosults would not be sienifl. cantly changed if both quantities were taken as constants.

The nocessary calculations are quite strelghtformard once an approxdmate expression for $p$ as a function of compression at constant entropy 18 knowm. The

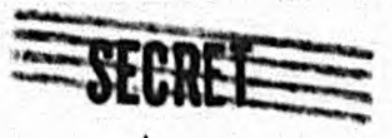




\section{ĐSERRE}

-7 -

emplofical form chosen is

$$
p_{s}=\alpha_{y} \mu+\beta_{s} \mu^{2}
$$

the entropy boing constant. The value of the constant $\alpha_{0}$ is inferred from known values of the velocity of sound and of the density under stundard laboratory conditions. Thus the dace doetred from shock moasurcments to used meraly to evaiuate the constant $\beta_{B^{\circ}}$. Scme question naturally arises as to how $\alpha_{s}$ is rolated to the observed sound velooity. Equation (17) is intended to apply to matorial under such great hydrostatic pressure that ang shearing stress is complotely negl1giblo both in 1ts magnitude and in 1ta effoct on the compresston $\eta$. Acoord1ngly, 1t would seem natural to evaluate $\alpha_{B}$ for conditions under which compression ocours without appreciable shearing stress. But detorninations of sound velocity In general are made elther with bars, for whlch $C_{1}=\sqrt{E / P}$ where $E$ is Young's modulus, or for large masses of material for wh1ch $C_{2}=\sqrt{\left(k+\frac{4}{3} G\right) / P}$ where $k$ 1s the bulk modulus and $G$ the shear nodulus. It is the isentrople bulk nodulus which relates pressure to compression when the shearing stross is negligible, and accordingly we have assumed that

$$
\alpha_{s}=\left(\frac{\partial p}{\partial \mu}\right)_{s}=-v_{0}\left(\frac{\partial b}{\partial v}\right)_{s}=K_{s}
$$

A value of $\alpha_{B}$ mey bo quickly dectuced from $C_{1}$, if Polsson's rat1o $\nu$ is lonom, or from $C_{2}$ if the velocity of shear vaves $C_{3}=\sqrt{G_{0} / P}$ is known. In the latter case, the computation is obvious; in the fortner,

$$
\alpha_{s}=E_{s} / 3(1-2 \nu)
$$

Host of the currently avaliable data on compresalbilities at exireme pressures have been obtained 1sothermally. These data may Illoulso be fittod well by an equation almilar to Eq. (17)

$$
b_{T}=\alpha_{T} \mu+\beta_{T} \mu^{2}
$$




\section{s5coer}

The relation between $\alpha_{B}$ and $\alpha_{\mathrm{I}}$ 1s well known to be

$$
\alpha_{s}-\alpha_{T}=\frac{v_{0} T}{c_{v}}\left(\frac{\partial p}{\partial T}\right)_{v}^{2} \text {. }
$$

The corresponding difference botween $\beta_{\mathrm{g}}$ and $\beta_{T}$ ls not so vell known, but may be urstten

$\beta_{s}-\beta_{r}=-\left(\alpha_{s}-\alpha_{T}\right)\left\{1-\frac{1}{2} v_{0}\left[\frac{1}{C_{v}}\left(\frac{\partial p}{\partial T}\right)_{v}^{+}+3 \frac{\partial^{2} \frac{p}{\partial v}}{\partial \tau} /\left(\frac{\partial p}{\partial T}\right)_{v}-3 \frac{T}{C_{v}}\left(\frac{\partial \psi_{p}}{\partial T}\right)_{v}-\frac{T}{C_{v}^{2}}\left(\frac{\partial p}{\partial T}\right)_{v}\left(\frac{\partial C_{v}}{\partial T}\right)_{v}\right]\right\}$.

In the course of developing experinental techniques with a view to determining what ultinate precision is possible, It was found convenient to use an alloy of alunimm with superior mechanical properties rather than the pure elenent for which stat1c compressibilitios are avaliable. In order to conpare the present work with that of others". It is desirable to estimate the effects of the alloying const1tuente.

P. W. Br1dgnan, Broc. An. Acad. 79 g $189,(1949)$

This can easily be done if one assumes that the volume of the alloy is oqual to the sum of the volumes of 1ts const1tuents. For mang alloys this assunption leads to an excellent estimate of the norral density, and it seems reasonable to expect that 1ts valla1ty is not appreciably vorse at high pressures. The subecripts (1) and (2) will be used to denote properties of the constituentss absence of oither of these denotes a property of the alloy. The additional subscript (0) refers to a property under standard laboratory conditions. Thus the equations of stato. Involved would be

$$
\left.\begin{array}{l}
p=\alpha \mu+\beta \mu^{2} \\
p=\alpha_{1} \mu_{1}+\beta_{1} \mu_{1}^{2} \\
p=\alpha_{2} \mu_{2}+\beta_{2} \mu_{2}^{2}
\end{array}\right\},
$$




\section{SECREI}

Wh1le the equation conneoting the various compressions is

$$
\frac{1}{p_{0}(\mu+1)}=\frac{x_{1}}{p_{0}\left(\mu_{1}+1\right)}+\frac{x_{2}}{p_{0}\left(\mu_{2}+1\right)}
$$

$x_{1}$ and $x_{2}$ denoting the rractions by nass of the respective constituents. Values of $\alpha$ and $\beta$ in terms of $\alpha_{1}, \alpha_{2}, \beta_{1}$, and $\beta_{2}$ may be approximated at omall compressions by implicit differentiation. Th1s approximation probably does not give very good average values over the extended range of compressions involved, but It should at least suffice to indicate whother or not observed dsserepanoles are of the bort to be expected beceuse of varintion in composition. The reguirod relations are

$$
\frac{1}{p_{0} \alpha}=\frac{x_{1}}{p_{01} \alpha_{1}}+\frac{x_{2}}{p_{2} \alpha_{2}}
$$

and

$$
\frac{\beta}{p_{0} \alpha^{3}}=\frac{x_{1}}{p_{01} \alpha_{1}^{2}}\left[\frac{\beta_{1}}{\alpha_{1}}+1-\frac{\rho_{0} x_{1}}{\rho_{01}}\right]+\frac{x_{3}}{\rho_{02} \alpha_{2}^{2}}\left[\frac{\beta_{2}}{\alpha_{2}}+1-\frac{\rho_{0} x_{2}}{\rho_{02}}\right]
$$

\section{EXXERDMPTALTECENIQUNS}

The essential detalls of the experimental technique for the necessary velooity determinatione may be vioueldsed by reference to $F_{1 g}$. 1. The material to bo studied is machined nto the form of a plate perhaps 8 inchos in diameter and of a thicleness governed by considerations to be discussed. A shock wnve 1s Induced In this plate by means of a large block of high explosive (Ho.) detonated almultaneousiy at all points of 1ts uprer surface by neans of a sultably designed high explosive lens. Detonation of the latter is initiated electrically in the usual way. At the upper surface of the plate, a high pressure pulse is produced, the magnitude of which depends on the type of high explosive used and the duration of which depends on the s1se and shape of the tigh explosive. In order to ochleve 


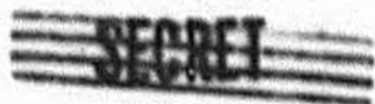

$-10-$

a condition of falrly constant preasure at the upper ourfece of the plate for an approelable length of $t$ ime the blook of $\mathrm{H} . \mathrm{E}$. wast be large. For al though the Instantaneous prossure in tho dotonated F. E. dopends primarily on 1to ohenlon and physical properties, the preasure genereted by the detonation is Imedintely relleved at the free surfaces by rarefaction waved. These rarefactions lialt the time avallable for the neecurements to a feu mioroseconds and also weans that portions of the plate near the aldes never recelve the full detonation presenre.

Sinoe the block of high explosive is neceesarily of finlte thielenesa (urually 3 to 4 1nohes), the shock vave in the plate resulting froe impact to the detonation wave in the explosive 18 not quite nat toppod. The ehock front 10 followed imiediately by a rarefuction from the back ourface whlch reault in an exponentiel decay. This unloeding wave, noving through the plete more rapidy than the shock rront, is oonsinally uhittling coum the poak preesure. In consequenoe it is necessary to nonoure the parameters as a runetion of thickness of the naterial.

The free surface velocity at the botton of the plate (F1g. 1) 1s escertalned by moans of externally placed electrical oontactors. These contadtori, or "PDis", show in F1gure 1, may be arranged to moacure o1ther freo surface velocity, by spacing thes out bohind the plate as ohown, or conpreasion wave velocity through the plate by insulfting and Imbodding the pins in holes drillod to various deptha. In elther case, the osc1llograph records the time at witoh each pin firot touches the metallic surface. In order to annchrontse the osc1llograph, on extra pin is irboddod in the plate at octe convenient level anondar to provide/an olectrical pulae for inftiation of the sweop.

Pressure may be measured Independently by weans of probes ande from 2-eut tourmaline dises. The calibration constent of the cryatels, for the geometry and conditions of theso tests, vas dotermined from monsurenente of $u$ and D In steol. It is advantageous to make those crystals thin. Ours aro thioker, 


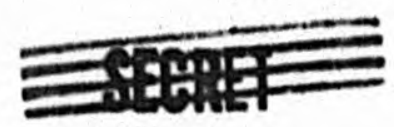

about $0.5 \mathrm{~mm}$, than desired but thi.e choice was dictated by practical consideration of existent constructional linstitions. Several reverborations are required for equilikrium to be attained between tergot and erystai and therefore a usenul crystal 11Pe of about 0.5 mlerosecond is required. If the crystal becones ahort-circuitod before this time a correction factor must be applied for the aooustic mismatch of crystal and specinen plate.

Most of the experimental work on wh1ch the prosent paper 1s based was performed in 1945. At that time it was realized that elaborate precautions would be required in order to improve the precision of the data. The recent work on duralumin is inclusive of various improvenents in techniog , wh1ch have boen discovered over the course of the last flve years.

In the first plece, if the pins are spaced out behind the plate as shown In Fig. 1, they may be prematurely connected to the plate and to one another by Ionization of the gas with which they are surrounded. Attenpts to insurate the pins from this lonization tend to result in ezratio conduction when the retallie ourface Itself arrives. Aftor moh Investigation, wioh Includod attempted evacuation of the space surrounding the pins, and ell sorts of Insulations for the pins thenselvee, It was discovered that little or no preconduction oocurs if the gas ourrounding the pins 1s one of the l1ght fydrocnrbons, 1.e. methane, ethane, propene or tutane. The "CAS TICHI CHAMPR" in Fig. I is always, in the more recent work, fllled with one of these guses.

Furthermore, the plone wave of compression as it proceeds through the plate rust be exceedingly regular. It is known that in ouch a oompression the pressure riso is exceedingly abrupt and that the emplitude of this abrupt rise is constant provided the material behind the wave is uniformly oompressed Constanoy of pressure behind tho shock front may bo epproxdastoly achlevod by using a sufflolently large block of high explosiva. If. Kowover, the wave 1.s not plane, 


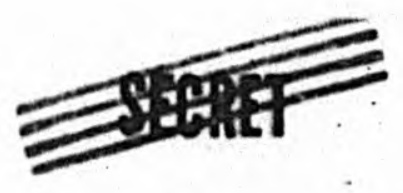

$-22$.

1ts space configuration varies as it proceeds, and if the cospression behind the rront is not uniform, the magnitude of the virtuaily disoontimuous pressure ohange 1s not constant. Furthermore, even if the wave is perfect in terns of the above criteria the plano of the waves may not be parallel to the plane of the plate. 1. variety of apocial precautions been introuluct to minimise effects of these possible souroes of error. Continual inprovement in the preparation of the "B. $E_{0}$ " and the "Isias" have virtually eliminated departures from planeness and tilt in the wave 1tself. A small residual t1lt of the front does not affect (to errors of the firat order) the inferred velocities if the "PIns" are propexly arranged in small c1rclos. In some exporiments, as many as nine cirales of elght pins each are used to supply simultaneous information.

In addition to the above difficulties it has been found that anall Irregularitios or scratches in the surface of the plate result in jets which may cause erratic pin discharge. Indeed owing to the poljerystelline structuro of the metal 1tself, scmo irregularitios in the moving froe surface are 1nvariably present, the magnitude of these Irregularities being of the order of the size of the Individual metallic crystal graing. Because of this unavoldable roughners, it is not preationl to asko rree surface velocity meesurenents over extrenely ohort ranges of motion. Ixperinent has shown, however, that theso irregularities are not too serlous if the total range covered by the pins exceeds $5 \mathrm{~mm}$

A further IImitation on the method results from the fact that in cortain natorials (0.G. steel) an elastic wave of compression moves with a higher velooity than the shock wave up to certain pressure which depends on the cynemic jleld (Seo F1g. 5) pointo. In such cases, the necessary information can be achseved by the use of plesouleotric eryatals (see FIg, 2 and 3 ).

Orie further technical experimental point deserves brief mention. As has been mentioned, some decas of pressure is encountered with increasing thickness of 


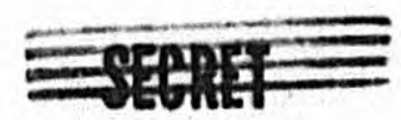

the plate. It is thus essontial that the shock wave velooity and the mass valocity be obteined for an oquivalent particle, ntmoly a particle closo to the roo surface of the plate. But the probes for measuring propagation velocity are perforce distributed through the thicknoss of the plate, and, since the anpiltude of the shock is varying, so also does the propagation velocity viry. The siraplest uny of finding shock velocity at the free ourface is to rake the portion of the plate where the shock velocity is measured somewhat thicker than the portion where tho free ourface velocity is meesured, so that an avorage value for the fornor will be compatible with the observod value of the latter.

Fron the neasured free surface velocity, the nass velocity of the compressed naterial nay be infarred. It 18, of course, necessary to complete the measurement of froe surface velocity before roverberations can occur in the target plate. Otherwise one obtoins a measure not of mess velocity but of momentum transfer from explosive to plate. Furthermore beceuse of the decay of pressure behind the shock front, one might expect the obserrod free surface volocity to disminish os the notion proceeds, but such an effect has not been dotecteds With these considerations in nind each set of $\&$ contactors is usunlly specoc over an interval of about $5 \mathrm{~m}$ from the baci. surfuce of the plate, though for very thin pletes an even closer spacing ray be necessary in opite of the uncertainties due to roughness of the moving free surfece as nentioned above, and the shorter reverieration timo.

In order to outain oxtengive date on the equation of state of tho material under study, It is necessary to produce in the specimon conpressional ohock waves of arbitrary empiltude. There ere three ways in which this has been accomplished

(1) By increasing the tilicioness of the speciton, the pressure decays naturally, because the amplitude of the pressure discontinuity remains constant

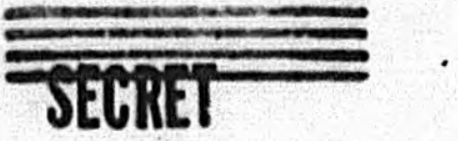




\section{-}

$-14-$

only if the pressure in the compressed material is everywhere uniform. With blocks of high explosive of finito dimensions, this condition is not satisfied, continuous

and a contemal degradation of shook pressure is always encountored.

(2) The detonation pressure may be varled by using different compositions of high explosive.

(3) The amplitude of the transmitted shock may be adjusted by placing an intermediate metal between the block"H.E." and the specimen "PLATE", as would be possible with acoust10 waves.

\section{OBSERVED DACA}

- The date obtained by the moasurements made in 1945 are summarized in the PIrat two oolums of Table II. The more recent measurements made on duralumin are listed in the first two columns of Tablo III.

Table II

\begin{tabular}{|c|c|c|c|c|c|}
\hline Materinl & $\begin{array}{l}\text { Shook } \\
\text { Veloc1ty }\end{array}$ & $\begin{array}{l}\text { Free Surface } \\
\text { Velootty }\end{array}$ & ${ }_{(\text {Computed) }}^{n-2}$ & $\begin{array}{l}\text { Pressure } \\
\text { (Computod) }\end{array}$ & $\begin{array}{l}\text { Pressure } \\
\text { (Crrstal) }\end{array}$ \\
\hline ALARInTus & 0.738 & $0.2 \%$ & 0.250 & $0,2 \%$ & $\cdots$ \\
\hline CADMITUI & 0.396 & 0.145 & 0.224 & $0.2 / 48$ & 0.231 \\
\hline $\begin{array}{l}\text { STEESL } \\
\text { Shook Have }\end{array}$ & $\begin{array}{c}0.510 \\
\text { (Average) }\end{array}$ & $\begin{array}{l}0.115 \\
0.165\end{array}$ & $\begin{array}{r}0.122 \\
0.195\end{array}$ & $\begin{array}{l}0.223 \\
0.332\end{array}$ & $\begin{array}{c}\text { (Callbration) } \\
0.324\end{array}$ \\
\hline Elast 10 Wave & 0.588 & $\begin{array}{l}0.0067 \\
0.00667\end{array}$ & 0.006 & 0.025 & 0.0257 \\
\hline
\end{tabular}

Tablo III

(24 ST Duraluaten)

\begin{tabular}{|c|c|c|c|c|c|}
\hline $\begin{array}{l}\text { Shook } \\
\text { Veloeltry }\end{array}$ & $\begin{array}{c}\text { Free Surface } \\
\text { Veloostry }\end{array}$ & $\begin{array}{l}\text { Mass Velocity } \\
\text { (Comruted) }\end{array}$ & $=\frac{\eta-1}{\text { (computed) }}$ & $\begin{array}{l}\text { Shook Presenure } \\
\text { (Comruted) }\end{array}$ & $\begin{array}{l}\text { Isentrop10 } \\
\text { Pressure } \\
\text { (Computed) }\end{array}$ \\
\hline $\begin{array}{l}0.61460 \\
0.6850 \\
0.7005 \\
0.7426 \\
0.7520\end{array}$ & $\begin{array}{l}0.1629 \\
0.2254 \\
0.2395 \\
0.3014 \\
0.3179\end{array}$ & $\begin{array}{l}0.0814 \\
0.1126 \\
0.1196 \\
0.1503 \\
0.1584\end{array}$ & $\begin{array}{l}0.14 / 2 \\
0.1967 \\
0.2059 \\
0.2538 \\
0.2668\end{array}$ & $\begin{array}{l}0.1462 \\
0.2144 \\
0.2329 \\
0.3103 \\
0.3312\end{array}$ & $\begin{array}{l}0.1435 \\
0.2079 \\
0.2250 \\
0.2952 \\
0.3139\end{array}$ \\
\hline
\end{tabular}




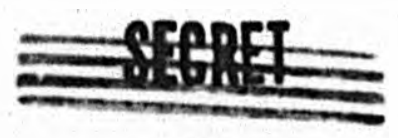

-25 -

In the two tables above, the recorded deta represent averages taken from a large mumber of individual deterninations. In Table II the standard deviation for both wave relocities is of the order of 2 percent. Unfortunatoly in the case of steel the presence of the elastlc wave renders the computation of shock pressure and compression somewhat uncertains the magnitude of the correction appears, however, to be 10 ss than 1 percent. In Table III the standard doviations as computed rrom the resicuals do not exceed 0.5 percent in and case. In complling both tables the original oscillographic data were analyzed by the method of least squares. Tablo II 1s based on the essumption that the measured free surface velocity is twice the mass velocity. In Table III a correction to this approximation has been made. All units are as specified in Table I.

\section{TUMERTCAL COMPUTATIONS AND RESULTS}

In order to reduce the shock pressures in Table II to adiabatio pressures, the data of Teble IV are required. The data of the first four columns were computed from material to be found in the usual sources, notably Biroh's Handbook", the Metals Handbook ${ }^{+}$, and the Handbook of Chemistry and Phgsios"

Table IV. Therriodynamic properties of selected elements.

\begin{tabular}{|c|c|c|c|c|c|c|}
\hline Element. & $P_{0}$ & $\alpha_{0}$ & $\sigma_{\nabla}$ & $\left(\frac{\partial \underline{b}}{\partial T}\right)_{v}$ & $\beta_{B}$ & (Bridgman) \\
\hline ALUMOIUS & 2.699 & 0.712 & 0.108 & 0.56 & 1.53 & $1.69 \pm 0.04$ \\
\hline CADMIOA & 8.65 & 0.48 & 0.014 & 0.46 & 2.20 & ---- \\
\hline STEEL & 7.84 & 1.69 & 0.054 & 0.46 & 0.8 & $2.4=0.1$ \\
\hline
\end{tabular}

The values of $\mathrm{B}_{\mathrm{g}}$ in the flfth column are those decuseed by correcting the data of Table II to 1sentropic conditions and then fitting Eq. (17) to the observed point.

Francis BIrch, Handbook of Physical Constants, Geological Soctety of America, 19/42

r American Soclety of Metals, Motels Handbook, $19 / 48$

F Chas. D. Hodgran, Handbook of Chemtst, and Phrater, Chem, Bub. Pub, Co., 1952 -víkit = 


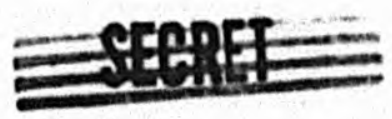

-16 -

In the case of steel, only the point obtained at the lower shook preseure was used In computing the value of $\beta_{B^{\circ}}$. At the higher pressure, the compited value of $\mu$ appeara to be much too large, and vould imply an oven smaller vilue of $\beta_{B}$. Further work will be required to verify the discrepanoy betwoen Bridgnan's work and ours, but the avallable data secen worth recording because of the Interest wh1ch may attach to the peak pressure as recorded to tho tournaline crystal, and the relatively good agreement between this presoure and that computed by Eq. (2). 


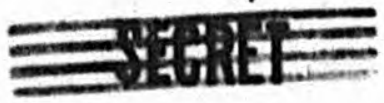

$-17-$

Values of $\beta_{g}$ may olso bo coraputed by an anelyols of Bridgan's latest work", and for alumimm and Iron these appear in the last columnor Tablo IV.

200. o1t.

The standard deviations for these values are aimply indications of the precision with which the enpirical equation of state fits the observed points, and should not be taken as an indication of the experimental accuracy. The relatively better precision shown in the case of the aluminum is due chiefly to the fact that the aluminum is much more compressible, so that a greater range of values of the compression are avallable for analya1s. The correction from $\beta_{T}$ to $\beta_{s}$ amounts to +0.01 for aluminum when computed by Eq. (22)/ 1t has not been computed for steel.

The corrections required to reduce the data of Table III are ohown Eraphloaliy in Fig. 40. The plotted values of $(\sigma-u) / u$ are subject to considerable uncertainty, but the values ahow for $p_{D}-p_{a}$ should be acourate to 5 percent or better. In analyzing the reduced data, a valuo $\alpha_{5}=0.760$ was arbitrarily nelected. Th1s value was inferred from measurenents of the veloolty of sound in duralumin. The method of least squares was then used to infer the value $\beta_{g}=1.57 \pm 0.02$ for this material. Correction for the presence of copper (of. Eqe. (25) and (26)) glves corresponding values for pure alumimm of $\alpha_{B}=0.753$ and $\beta_{B}=1.53$. Correction of these to 1sothermal conditions (of. Eqs. (2d) and (22)) gields $\alpha_{T}=0.726, \beta_{T}=1.52$. Corresponding coefficients computed rrom Bridgman's data again by the method of least squares are $\alpha_{T}=0.725 \pm 0.001, \beta_{T}=1.68 \pm 0.04$. The discrepancy between the two values of $\alpha$ is of no inmediate concern, since the shook wave measurements are not used for this deternination. However, part of the discreprancy botween the two values of $\beta_{T}$ is due to the fact that the $\alpha$ 's do not agree. If our arbitrary choice of $\alpha$ is made in such a way as to give agreemont 


\section{SEGRE}

$-18-$

with the figure deduced from Bridgnan's work, then the discrepancy between the B18 drops from 0.16 to 0.11 . One might reasonably inquire as to whether a threeterm equation of state would better fit our data, and yield botter agreement botween our results and Bridgman's. Unfortunately if the second order coefflcients were made to agreo, the third order coefficient as deduced from our data would be negative, and hence could hardly be useful for purposes of extrapolation.

\section{CONCLUSIONS}

Determination of shock and mess velocities in materials subject to 0.3 explosive stress ylelds data for equations of state up to megabar or more. . With care the precision attainable is about 0.5 percent on the velocity measurements, but because of the extreme pressures that may be reached, even this precision provides a more precise determination of the second order term in the equation of state than 18 possible with stat1c measuremerts. In the case of aluminum part or all of the discrepancy between the coefficlents determined staticelly and those determined dynamically may be due to the different pressure ranges to which the respective messurements apply, though the sign of the discrepancy suggests that this explanation is insdequate.

In Fig. I there has been included an estimate of the final temperature Increase in the duralumin after the expansion to atmospheria pressure. (This estimate is based on the entropy change as calculated by Eq. (16), and has been converted to Celsius degrees.) It will be obsorved that the melting point of the aluminum would be reached by 0.6 -megabar shock, and 1t soems likely that 
the measurements would becone impraoticable under these conditions. In any event the problem of corrocting free surfece velocity to obtaln mass velocity would become much more complicated.

A final word about precision secms in order. It might be imagined on cesual exrmination of Eqs. (1) and (2) that $D$ and $u$ mist be deterrined with equal precision in ordor to obtain useril data on the equation of state. Fortunataly, however. $u$ need not bo known with as great precision as $D$. To show this, let us consider the problem of determining $\beta$ in terms of $u$ and $D$ by menns of Eqs. (1). (2), and (27), aseuming $\alpha$ to be known. The fractional error $\alpha \beta / \beta$ to be feared in $\beta$ due to fractional errors $\Delta u / u$ and $\Delta D / D$ in $u$ and $D$ respectively 1s

$$
\frac{\Delta \beta}{\beta}=\frac{u}{\beta} \frac{\partial \beta}{\partial u} \frac{\Delta u}{u}+\frac{D}{\beta} \frac{\partial \beta}{\partial D} \frac{\Delta D}{D}
$$

Calculation reveals that for the duralumin, at the highest prossure attained,

$$
\frac{u}{\beta} \frac{\partial \beta}{\partial u}=-1.9 \quad \text { and } \frac{D}{\beta} \frac{\partial \beta}{\partial D}=+7.8
$$

so that four timee the precision 1s required on $D$ to make the errors of equal magnitude. Accuracy of 0.5 percent on $D$ would inply 4 percent aceuracy on $\beta$. In view of the fret that five points were used for our final deternination of $\beta$, the calculated standerd deviation of a 11ttlo leas than 2 percent appears to be compatible with these considerations. 


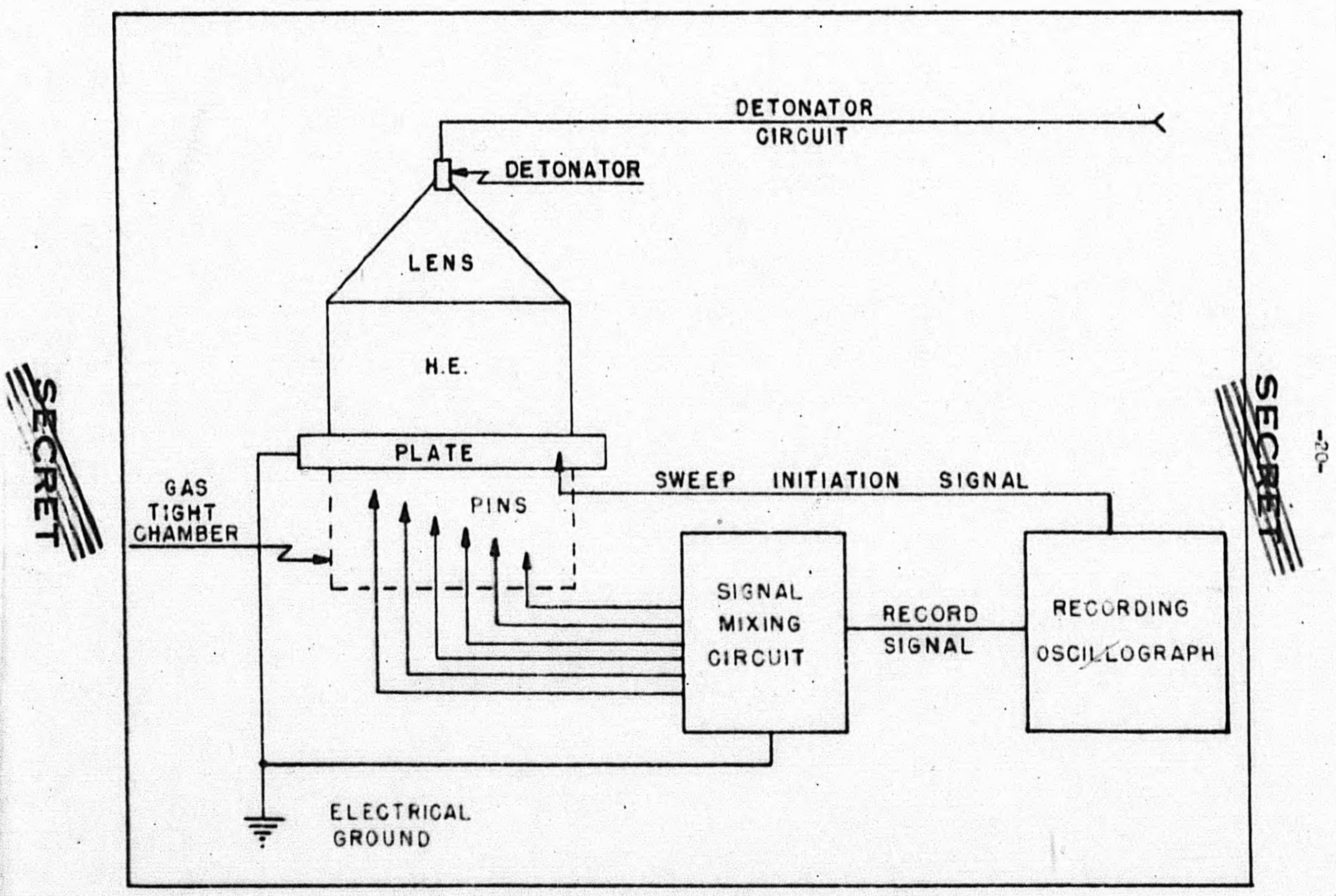

PHG. 1 APPARATUS FJR DET RUIMINO FREE SURFACE VELOCITY 


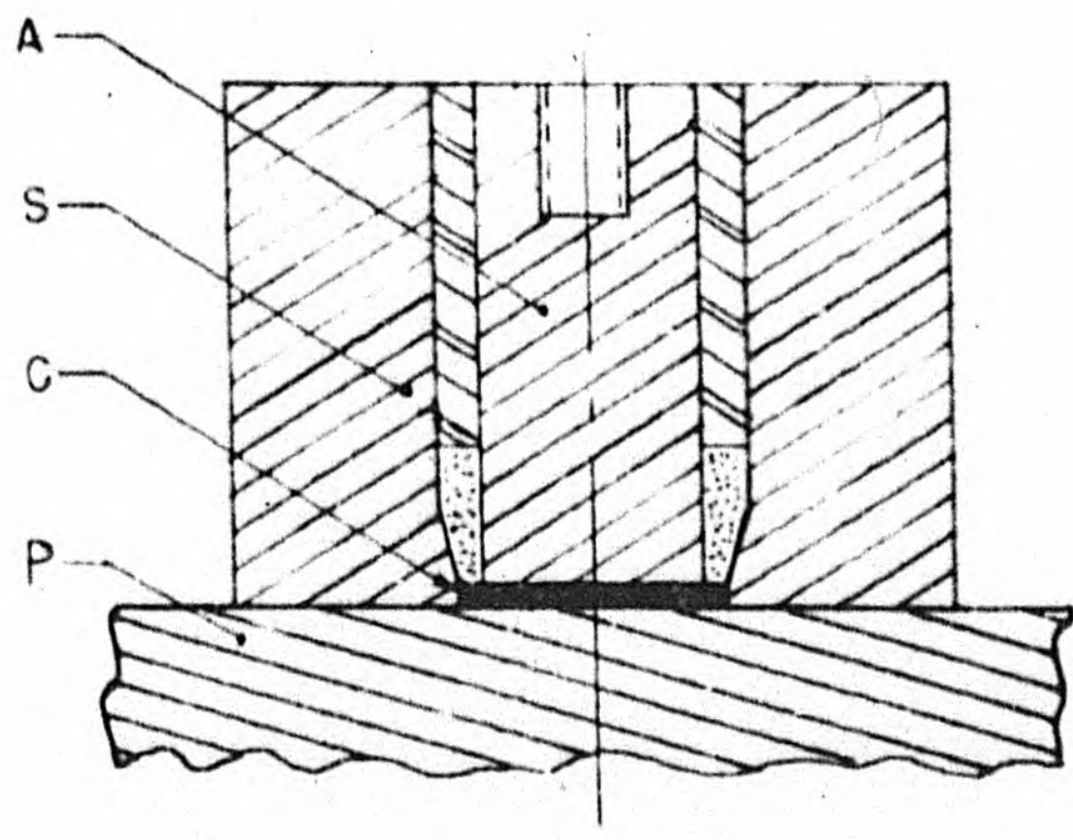

Figure 2. Assembly for holding piezo-electric crystal in place.

A. Metal electrode and inertial support for crystal.

s. Quard ring.

C. Crystal.

P. Specinan through which shock wave proceeds. 

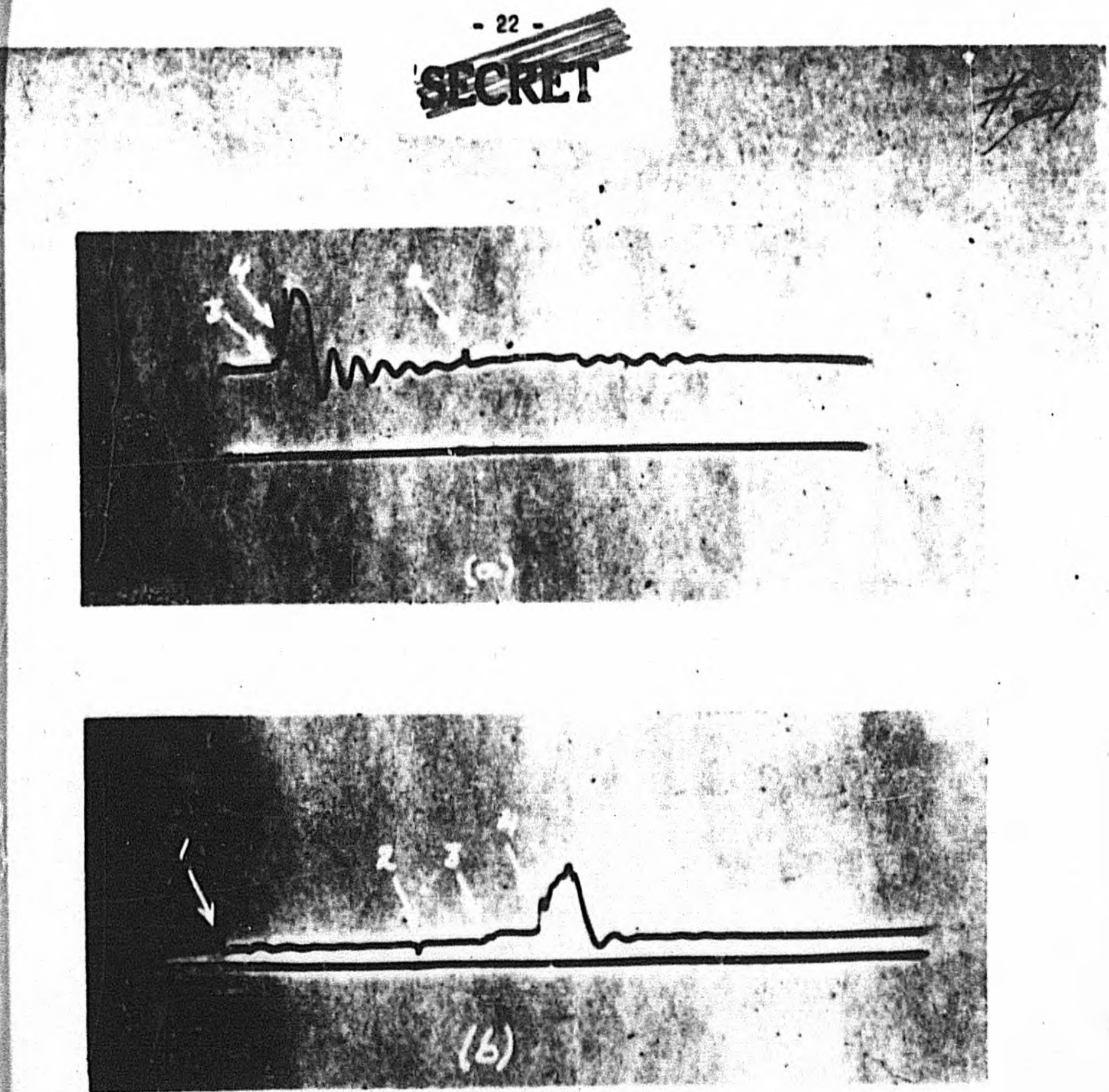

Hg. 3. cooldlegraph reoorde of ohookeveve profide after neving through

(a) $0.25 \circ$ (b) 2.250 of 6454940 oteod. (1) 20 orees talk frea (a)t

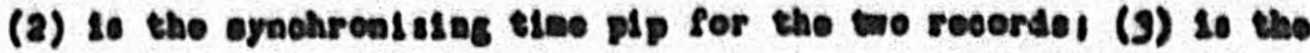

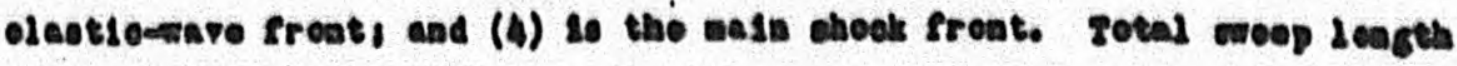

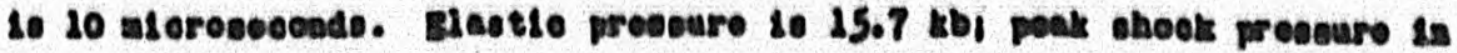

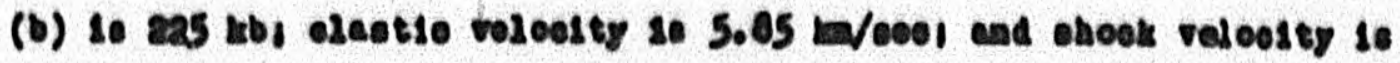

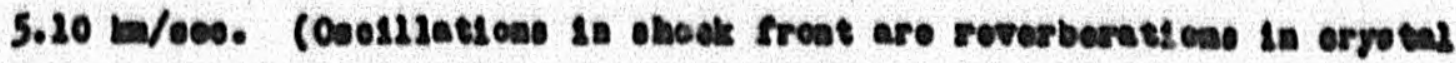

probos.)

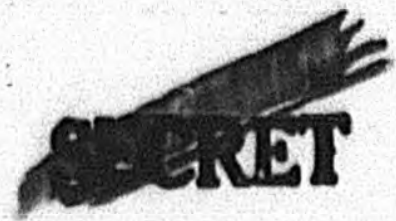




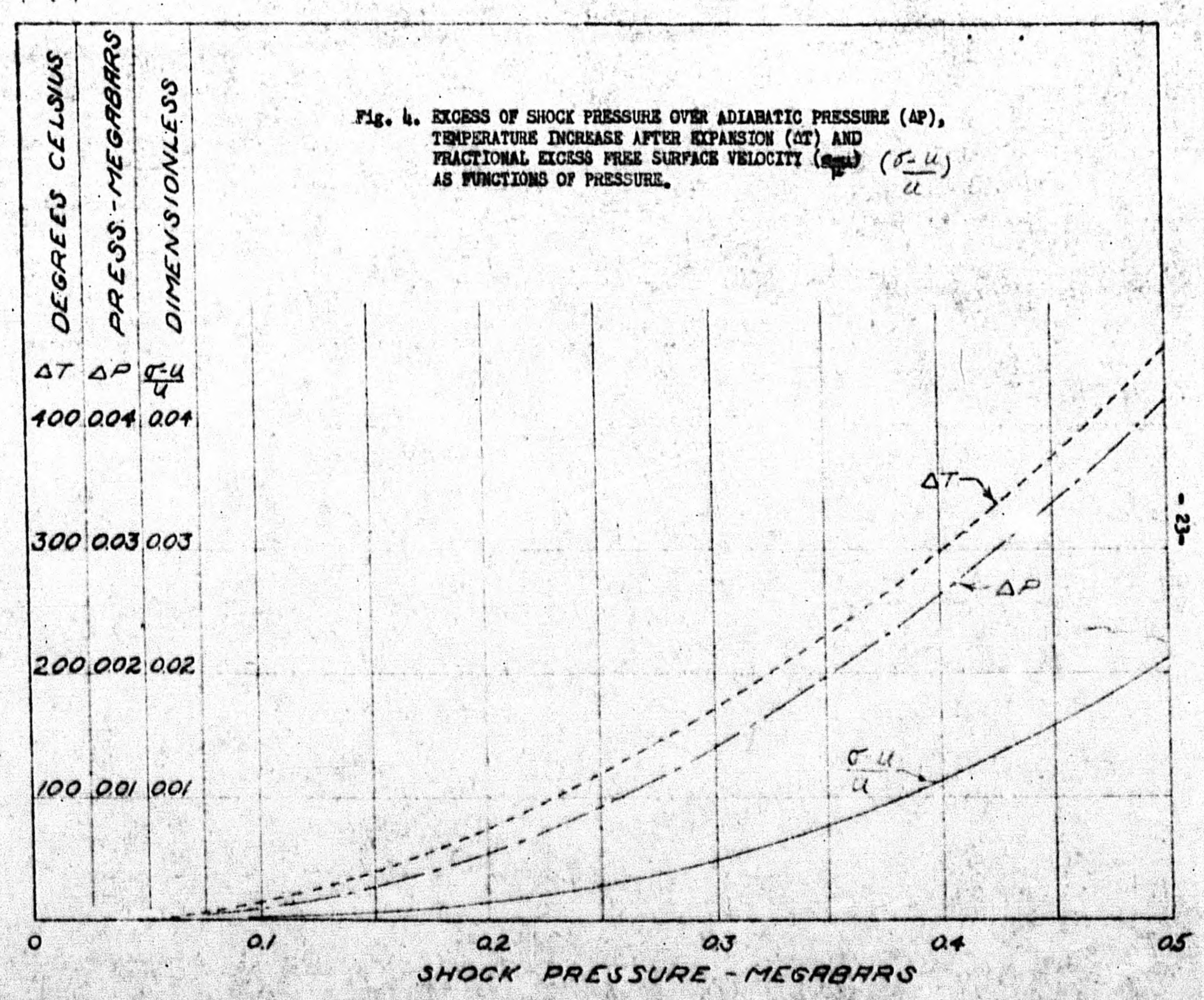




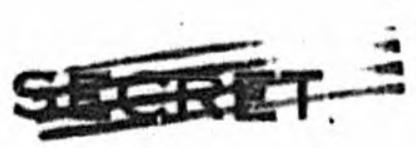

Fig. 5. Solid line represents a hypothetical isentropic equation of state of steel subjected to uniaxial conpression, showing effect of shearing stress below the dynamic yield point $Y_{e}$ Shock wave velocity is given by the expression

$$
D=v \sqrt{\frac{\Delta p}{\Delta V}}
$$

where $\nabla$ is the specific volume of the material ahead of the shock, $\Delta p$ is the incremental shock pressure, and $\Delta V$ the change in specific volume due to the shock.

\section{compressional}

Below the dynamic yield point, waves are propagated with the sound velocity, proportional to the square root of the slope of the solld line. compressional

Above dynamic yield point, waves are propagated with velocities proportional to the square root of the slope of the dotted lines, Note that extreme pressures on dotted lines lie above the isentropic, due to entropy change under shock conditions. - Upper dotted line represents a shock traveling with the velocity of sound at low pressures, 1.e. a shock not preceded by an elastic neve. 


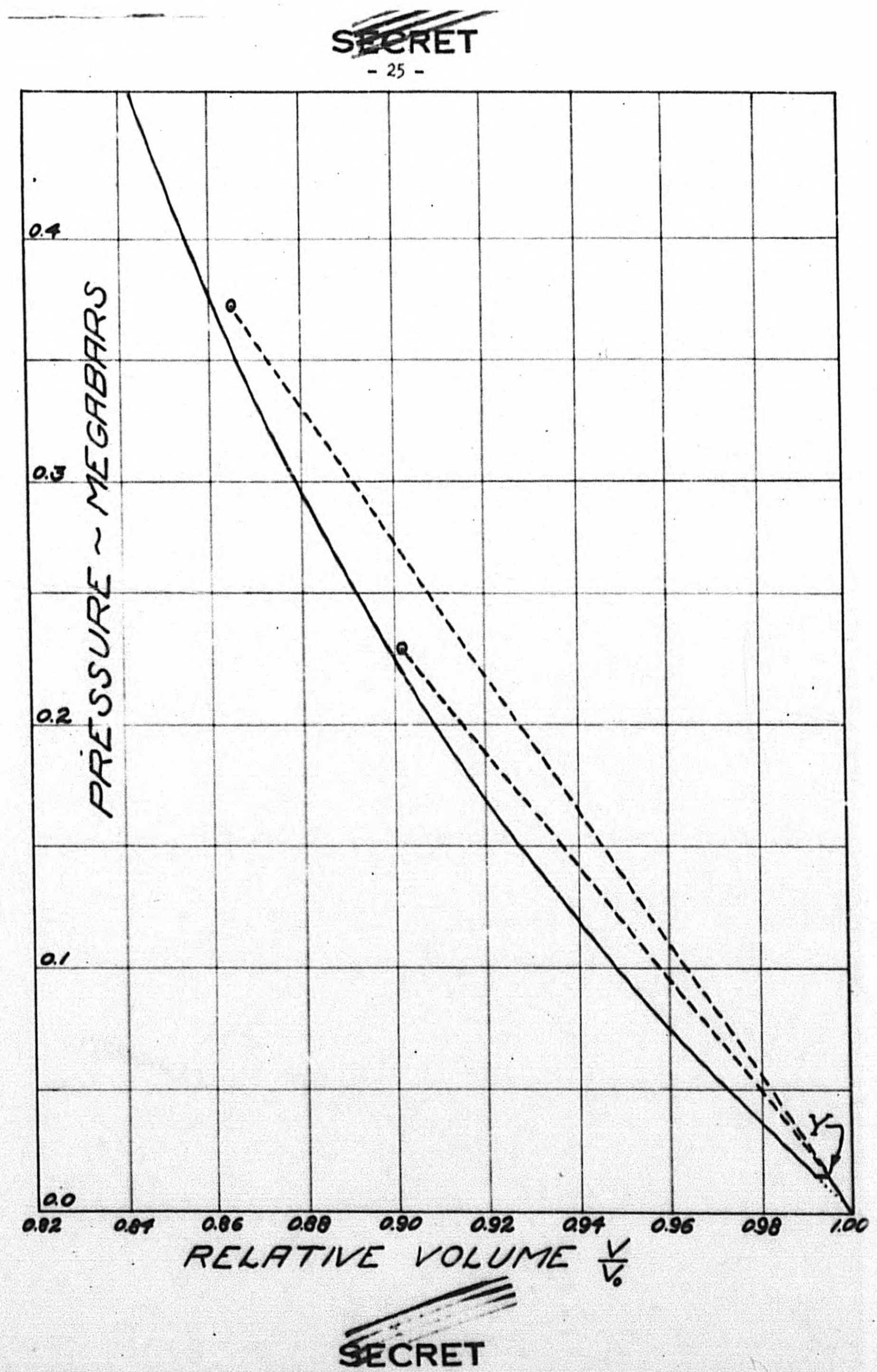




\section{SEC}

ABSTRACT

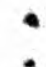

$\checkmark$

Equation of State data for duralumin in the pressure range

from 0.1 to 0.3 megabar have been determined dynamically by measuring

shock and free surface velocity electrically in a plate of $24 \mathrm{ST}$ duralumin

which has been stressed by a high explosive detonation. The theory is

presented which allows comparison with date obtained by other experimenters,

requiring the relationship between pressure and compression either af

constant entropy or constant temperature. The empirical form chosen for the equation of state $p=\alpha \mu+\beta \mu^{2}$ expresses the pressure as a quadratic function of the compression. Bxperimental techniques are described in deta1l. Five points are given for equation of state of duralumin in the pressure range from approximately 0.15 megabar to 0.33 megabars. Somo data are also presented for cadmium and oteel.
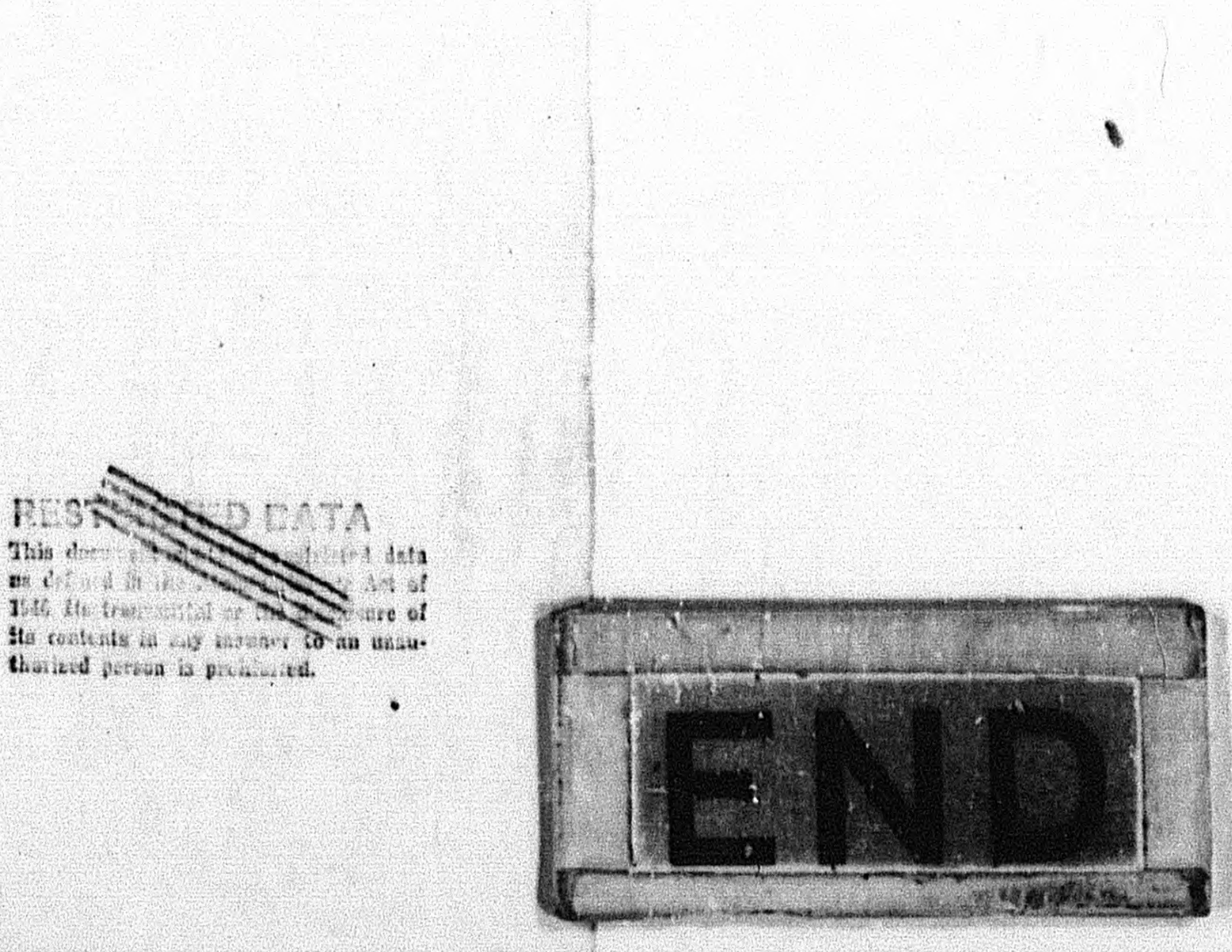